\title{
Foreign Remittance Income in Bangladesh: Opportunities and Challenges
}

\author{
Sheikh Abdur Rahim ${ }^{1}$, Md. Asraful Alam² \\ ${ }^{1}$ Assistant Professor, Department of Business Administration, Daffodil International University, Bangladesh \\ ${ }^{2}$ Senior Administrative Officer, ASA University Bangladesh, Bangladesh
}

\begin{abstract}
A remittance is a transfer of money by a foreign worker to his or her home country. Remittance can also refer to the accounting concept of a monetary payment transferred by a customer to a business (Wikipedia, the free encyclopedia). Remittances have been playing a very significant role for the overall economic development of Bangladesh. Therefore, this paper attempts to explore the actual remittance income and its impact on overall economy of Bangladesh. Recently, the world has suffering from the global financial crisis. That is why, the job opportunities are shrinking drastically for the last couple of years. As a result, the government of Bangladesh is now facing tremendous challenges to send people abroad for employment. Thus, this paper also attempts to clearly articulate the opportunities and challenges of remittance income in Bangladesh and suggested some possible courses of action to face these challenges with smart at hand.
\end{abstract}

Keywords: Remittance, Income, Opportunity, Challenge, Bangladesh.

\section{INTRODUCTION}

$\mathrm{R}$ emittances have already been emerged as a prime driving force to the economic growth and poverty alleviation in Bangladesh. It has obtained second position among the foreign currency earnings sector of Bangladesh. (Bangladesh Bank, 2012). Formally, the export of manpower from Bangladesh has been started in 1976. In this year there are fourteen thousand people gone to the Middle East for searching employment and in this year these people had sent 5 crore USD remittance to Bangladesh. After that, the amount of remittance and the numbers of migrant workers have been increasing gradually.

The export of manpower is one of the most significant foreign currency earning sectors of Bangladesh. It contributes our national economy in a large measure by increasing foreign exchange reserve, per capita income and employment opportunities. The remittance which has sent by the migrant workers is the 11 percent of the total GDP (Gross Domestic Product) in Bangladesh. Beside this, these remittances are 7 times higher than the amount which has got the government of Bangladesh as foreign aid and 13 times higher than the amount which got the government of Bangladesh as foreign investment. There are approximately 90 lakh Bangladeshi workers working in 155 countries in the world (Ministry of Expatriates' Welfare and Overseas Employment, 2012). Most of the workers are inhabitant of villages and granaries in Bangladesh. They don't get any government cooperation and subsidy. They have no higher education, training, and asset. But these people are pulling-up the economy of the country by hard working in abroad. They are living far away from their family members and they have been depriving themselves from the love and affection of their family members.

According to Bangladesh Bank Research Report (2012), among the migrant workers, 47 percent have gone to abroad by lending money from others and 41 percent have gone by selling land or leasing land to others. A large part of these migrant workers is unskilled or semiskilled. As a result, they have sent a large part of their income to Bangladesh. Most of the migrant workers families are maintaining activities with this money. The government becomes more beneficial than family members of migrant workers. The government gets huge foreign currency. The foreign remittance income is not only increasing foreign currency reserve but also playing a significant role to reduce poverty and to enhance the economic development of Bangladesh (World Bank, 2012). Bangladesh would be middle income country within 2021 depending on the foreign remittance income (Minister, Ministry of Expatriates' Welfare and Overseas Employment, 2012). The foundation of economy of Bangladesh becomes stronger with the help of valuable and hard -working money of migrant workers. The flow of amount of remittance would be one thousand four hundred crore USD (Immigration and Development Division, World Bank, November 20, 2012). The position of Bangladesh is seventh in the world remittance income. Bangladesh obtains the position in the world remittance income to the next of India, China, Philippine, Mexico, Nigeria and Egypt. The contribution of migrant workers has been playing a very significant role to the development of socio-economic condition in Bangladesh (General Director, BMET, 2012). The remittance income of migrant workers is not only increasing foreign currency reserve of Bangladesh Bank 
but also developing their standard of family life. The power of investment of these migrant workers is increasing day-by-day in Bangladesh.

\subsection{ObJectives Of The Study}

The present research study has been undertaken with the following objectives:

I) To investigate and find out the remittance income of Bangladesh;

II) To know the significance of remittance income for the economic development of Bangladesh;

III) To explore the potential opportunity of remittance income in Bangladesh;

IV) To find out the problems of remittance income of Bangladesh; and

V) To recommend some suggestions based on findings to overcome the barriers of remittance income in Bangladesh.

\subsection{LIMITATIONS OF THE STUDY}

Due to time constraint, the authors could not collect enough information from the secondary sources. The main limitation of the study is that the authors could not use primary data/information to analyze the study and find out the concrete results relating to opportunities and challenges of remittance income of Bangladesh.

\section{Research Methodology}

This research study has been conducted and analyzed on the basis of secondary data and information. The sample period of these secondary data and information is 20032012(November). These data and information were collected from different A-ranked journals, articles, published books, conference proceedings, newspapers, and magazines. A large part of this research report's data and information was collected from the website of Bangladesh Bank, Ministry of Expatriates' Welfare and Overseas Employment, Bureau of Manpower, Employment and Training, and the World Bank.

This research paper focused on two things. First, it highlights the remittance income of Bangladesh. Later, it investigates and find out the opportunities and challenges of remittance income in Bangladesh. Adobe Illustrate ${ }^{\circledR}$ has been used in data processing and Microsoft Office ${ }^{\circledR}$ package has been used in tabular, chart, and graphical representation of data and information.

\section{REVIEW OF Literature}

Remittance has been playing a very significant role to the sustainable economic development of a developing country like Bangladesh. The government has used remittance to pay the different government and non-government import bills and the installments of different foreign debt and donation. Salim (1992) point out that remittances are used to make import payments and are used for productive investment by the government. Ali (1981) identified

Copyright (C) 2013, Asian Business Consortium | ABR overseas remittances achieving a favorable balance of payments and as well as creating a new resources base for the country. A large portion of remittance income is spent for consumption purposes, acquisition of assets, investment in trade and business and to finance import of capital goods in Bangladesh. It has been positively affecting the socio-economic condition of migrant families.

Remittance income of Bangladesh is recorded as the second highest foreign currency income. Bust if the cost of import of raw material is adjusted, then the net earning from migrant workers' remittance is higher than that of the garments sector. According to Bangladesh Bureau of Statistics (BBS), in 2012, net export earning from RMG is USD 11.287 billion, whereas in November, 2012 the earning from remittance is net USD 12.87 billion. But the government expects that the remittance income will cross USD 13 billion at the end of the year 2012 (Bangladesh Bank).

Remittances are not a new thing in the world. It beings a normal concomitant migration, which has always been a part of human history. Several European countries such as Spain, Italy, and Ireland were heavily dependent on remittances received from their immigrants during the 19th and 20th century. In the case of Spain, remittances amounted to the 21 percent of all its current account income in 1946. All of those countries formulated policies on remittances developed after significant research efforts in the field. For instance, Italy was the first country in the world to enact a law to promote remittances in 1901 while Spain was the first country to sign an international treaty with Argentina in 1960 to lower the cost of the remittances received (Wikipedia, the free encyclopedia).Bangladesh needs to enact a law in the Parliament through proper discussion with all the stakeholders to protect this valuable sources of income.

Based on the above literature, it is clear that an extensive research is needed for the government and migrant workers of Bangladesh. For this very reason, the researchers have selected this topic to conduct the current research study.

\section{Meaning of Remittance}

A remittance is a transfer of money by a foreign worker to his or her home country. Remittance can also refer to the accounting concept of a monetary payment transferred by a customer to a business (Wikipedia, the free encyclopedia). A person who was exiled and has sent money to his or her home country, called remittance.

Dilip (2002) defines workers' remittances as the sum of three components: (I) workers' remittances recorded under the heading "current transfers" in the current account of the balance of payments; (II) compensation of employees which includes wages, salaries, and other benefits of border, seasonal, and other non-resident workers ( such as local staff of embassies) and which are recorded under the "income" sub- 
category of the current account; and ( III) migrant transfers which are reported under "capital transfers" in the capital account of the IMF's Balance of Payments Yearbook ( item codes 2391,2310, and 2431 respectively).

\subsection{SignificANCE OF REMITTANCE INCOME FOR BANGLADESH ECONOMY}

Remittances have been continuously playing an increasingly large role to the economic growth and the livelihoods of people in Bangladesh. Remittance income is more valuable for any developing country like Bangladesh. Puri and Ritzema (2001) tell that remittance is the portion of international migrant workers' earnings sent back from the country of employment to the country of origin, play a central role in the economies of many labor sending countries. Osmani (2004) tells that remittances have been identified as one of the three factors that have been responsible for reducing the overall incidence of poverty in Bangladesh. The demand of migrant workers remittances has now increased tremendously in Bangladesh in a number of reasons. These are as follows:

1. Remittance contributes to our national economy is a large scale by increasing foreign exchange reserve, per capita income and employment opportunities.

2. It has been continuously lifting-up the GDP (Gross Domestic Product) of Bangladesh. In 2012, the remittance which has sent by the migrant workers is the 11 percent of the total GDP of Bangladesh.

3. Remittance has been continuously keeping the contribution to alleviate the poverty of Bangladesh through micro-enterprise development, generating substantial employment and income.

4. The government has been paid various government and non-government import bills and installments of different foreign debt \& donation from the remittance income.

5. Remittance income helps the government of Bangladesh to reduce dependency on foreign aid.

6. Remittance helps to improve the balance of payment position of Bangladesh.

7. Remittance also contributes to the expansion of financial market activities and the development of payment systems through enhancing direct capital flows and distributing those funds to users end and for investment or finance consumption purposes.

8. The government of Bangladesh is using remittance income to build schools, colleges, universities hospitals, roads, \& highways, bridges, culverts, etc.

9. Remittance income is positively the socio-economic condition of migrant families.

10. Remittance income makes more strong local currency (Bangladesh) against US dollar.

\subsection{DETERMINANTS OF REMITTANCE INCOME IN BANGLADESH}

Bangladesh has been continuously received robust remittance because migrant workers are working hard and earning huge money in abroad. With these remittances, the government has been compensating trade deficit. The determinants of remittance in Bangladesh include employment in abroad, GDP growth, exchange rate and oil price. These determinants are strongly influencing on the level of remittance inflow of Bangladesh. Hussain and Naeem (2009) point out the following things:

1. Each additional migrant worker brings in $\$ 816$ in remittances annually;

2. Every dollar increase in oil price increases annual remittance by nearly $\$ 15$ million;

3. Depreciation of exchange rate by one taka increases annual remittance by $\$ 18$ million; and

4. Remittances are higher during periods of low economic growth.

\subsection{Migration Process in Bangladesh}

The process of migration in Bangladesh is shown in the following figure:

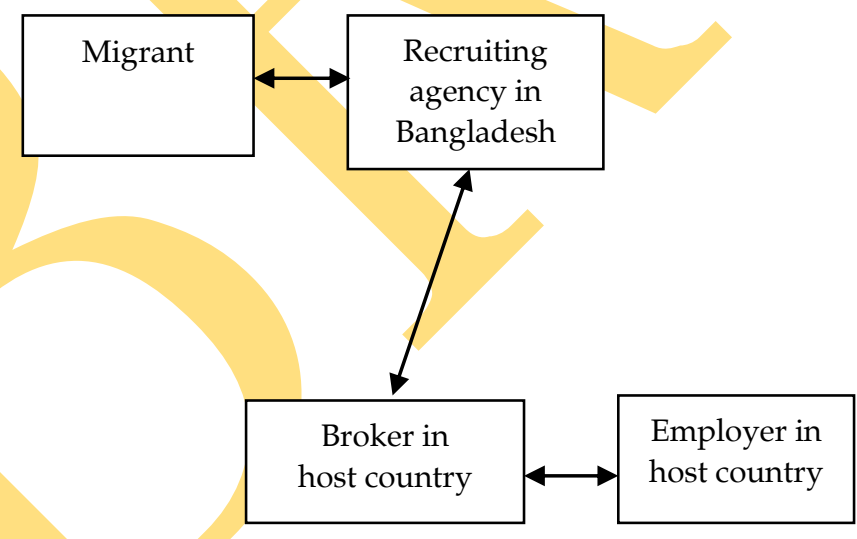

Figure -1: The Migration Process in Bangladesh (Source: UNDP-Bangladesh Migration and Remittances 080120.doc, Page-6)

In the above figure we can see that recruiting agencies are playing a very significant role in the migration of Bangladesh. These agencies must be licensed by the government of Bangladesh. They collect information about the demand for jobs in abroad from the brokers in the host countries who are directly related with the prospective employers (See Figure-1). The prospective migrants are facilitated by the recruiting agencies in securing passports, making travel arrangements and obtaining clearance from the Bureau of Manpower, Employment and Training (BMET). The recruiting agencies had organized themselves under the Bangladesh Association of International Recruiting Agencies (BAIRA) to enhance their interest and interact with the government in 1984. The government of Bangladesh had established the Bangladesh Overseas Employment Services Limited (BOESL) to compete with private agencies in operating direct recruitment. 


\subsection{FLOW OF LABOR MigRATION IN BANGLADESH (2003- 2012, NOVEMBER)}

\begin{tabular}{|l|c|}
\hline Edition & $\begin{array}{l}\text { Number of Labor Mi- } \\
\text { gration }\end{array}$ \\
\hline 2003 & 254190 \\
\hline 2004 & 272958 \\
\hline 2005 & 252702 \\
\hline 2006 & 381516 \\
\hline 2007 & 832609 \\
\hline 2008 & 875055 \\
\hline 2009 & 475278 \\
\hline 2010 & 300702 \\
\hline 2011 & 568062 \\
\hline $\begin{array}{l}2012 \text { ( Novem- } \\
\text { ber) }\end{array}$ & 575389 \\
\hline
\end{tabular}

Table-1: Flow of Labor Migration in Bangladesh (2003- 2012, November) [Source: Kalerkantho, January 10, 2013 (Special Issue)

The above table shows that the flow of labor migration in Bangladesh has been increasing until the year 2008. In case of labor migration in Bangladesh, the 2007 and 2008 editions were good because the record numbers of workers have gone to abroad these years for employment. Later, it has been continuously to decline over the next two consecutive years because of global financial crisis. Due to the global financial crisis, the owners of business organizations in the Middle East countries are bound to close their business operations. In addition to Middle East countries, the owners of other countries in the world are also bound to close their business operations because of global economic crisis. As a result, the flow of labor migration in Bangladesh has been declining drastically in the years 2009 and 2010. Again, the flow of labor migration has been increasing in the years 2011 and 2012. Thus, the government should find out the new-new labor markets to enhance the export of labors in the upcoming years.

The flow of labor migration in Bangladesh can be shown in the following figure:

\section{Number of Labor Migration}

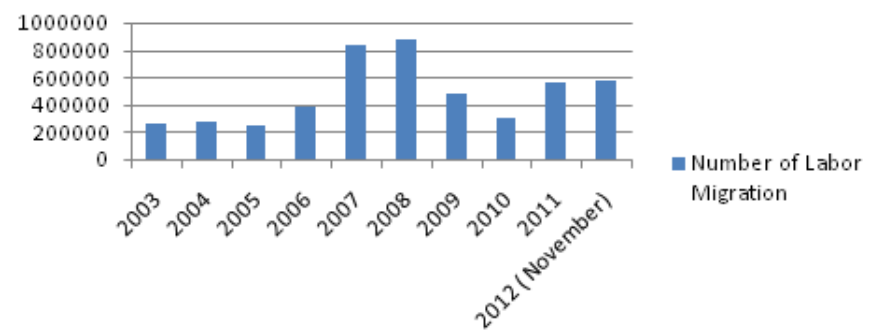

Figure-2 Flow of Labor Migration in Bangladesh (2003-2012, November) Source: Authors' calculation based on Kalerkantho Daily News Paper, January 10, 2013 (Special Issue)

The above figure shows that the trend of labor migration of Bangladesh is gradually increasing up to the year 2008. The flow of labor migration in Bangladesh was so good in the years 2007 and 2008. After that, the flow of labor migration is decreasing up to the year 2012 ( November) due to the economic recession, collapse of the construction and other business sectors in the Middle East countries and stopped the Malaysia labor market for Bangladeshi migrants and so on. Again, the flow of labor migration of Bangladesh is increasing in the years 2011 and 2012. So, this is very good news for migrants and government of Bangladesh.

\subsection{FLOW OF REMITTANCE IN BANGLADESH (2003-2012, NOVEMBER)}

\begin{tabular}{|c|c|}
\hline Edition & Remittance ( B.D in Billion USD) \\
\hline 2003 & 3.18 \\
\hline 2004 & 3.56 \\
\hline 2005 & 4.25 \\
\hline 2006 & 5.48 \\
\hline 2007 & 6.57 \\
\hline 2008 & 9.01 \\
\hline 2009 & 10.72 \\
\hline 2010 & 11.00 \\
\hline 2011 & 12.17 \\
\hline 2012 ( November) & 12.87 \\
\hline
\end{tabular}

Table-2: Flow of Remittance in Bangladesh (2003-2012, No-

$$
\text { vember) }
$$

Source: Kalerkantho, January 10, 2013 (Special Issue)

The above table shows that the flow of remittance income of Bangladesh is increasing.

Although the flow of labor migration is decreasing after the year 2008 but the flow of remittance income of Bangladesh is increasing. The reasons are that the government and private recruiting agencies have taken various initiatives such as pre-departure training (language, culture, custom, value system, rules \& regulations of the host countries), monitoring (within and outside the country) and diplomatic \& high profile discussion with the government and private owners of the host countries. Through these activities, the government and private recruiting agencies can send more people abroad which will increase the remittance income of Bangladesh. The flow of remittance in Bangladesh can be shown in the following figure:

\section{Remittance ( B.D in Billion USD)}

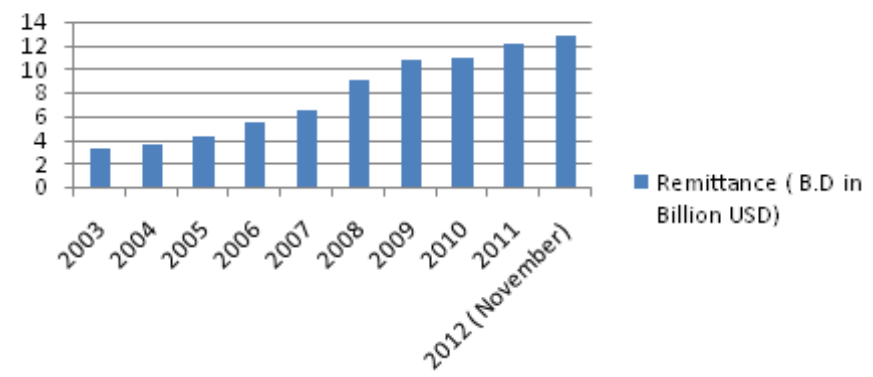

Figure-3: Flow of Remittance Income in Bangladesh (20032012, November) Source: Authors' calculation based on Kalerkantho Daily News Paper, January 10, 2013 (Special Issue) 
The above figure shows that the flow of remittance income of Bangladesh is increasing in trend over the year 2012 (November). The reason is that the government and private recruiting agencies have taken various initiatives to send skilled, competent and trained workers to abroad. That is why, although the flow of labor migration is decreasing but the flow of remittance income is increasing of Bangladesh.

\section{Channels of Remitting in Bangladesh}

Both the formal and informal channels are using by Bangladeshi migrants to send their remittances to their relatives at home. Among the formal channels, two channels are common, such as draft issued by a bank or exchange house and electronic funds transfers into accounts. Some government banks such as Sonali Bank Limited, Janata Bank Limited, Agrani Bank Limited and Some private commercial banks such as Bank Asia Limited, Prime Bank Limited, AB Bank Limited, United Commercial Bank Limited, Mercantile Bank Limited, Citibak N.A. and Social Islami Bank Limited are very much active in the remittance market. Among the informal channels, the most used channel is hundi system. The sender and remitter are avoiding tax and violating foreign exchange rules \& regulations that may facilitate money laundering.

DFDI and Bangladesh Bank have been selected BURO Bangladesh to act as a channel to transfer fund to the recipients from the foreign remitters. The title of the project is "Capacity Building to Enable BURO to provide Remittance Services to Commercial Banks". The aim of the project is to establish BURO, in collaboration with the community, with a strong positive image among the most productive and efficient bridges between the commercial banks and community in remittance industry. The goal of the project is to enable BURO to deliver remittance related services to commercial banks. There are 325 remote branches already established along with the terminal facilities include Electronic Funds Transfer Point-of-Sale and a Computer Package with internet connectivity. IFAD has already given award to BURO Bangladesh for a new project to expand the remittance services to extreme rural areas.

\section{Challenges facing by Bangladeshi MIGRANTS}

The migrant workers of Bangladesh have been contributing immensely to the economy with strong positive impact on growth, employment, foreign reserve and balance of payments. The country's imports would have to be drastically cut down or its current account deficit rose to highly unsustainable levels without foreign remittance. But these migrant workers are regularly facing various types of problems within and outside the country. The following problems are facing by Bangladeshi migrants within and outside the country:

Copyright (C) 2013, Asian Business Consortium | ABR
1. The people who want to go to abroad for job are suffering from information problem because most of these people are illiterate and they don't know from where they can collect more authentic information in this regard.

2. The people who want to go to abroad for employment are suffering from financial problem because most of these people are poor and they don't have ample resources. However, the non-government cost of migration is very high in Bangladesh and it is almost impossible to bear by these poor people.

3. The people who want to go to abroad for doing job are suffering from efficiency problem because most of the migrant workers of Bangladesh are unskilled and low-skilled. That is why, they can't perform their assigned task \& duties with effectively \& efficiently like the migrant workers of other countries in the world.

4. Bangladeshi migrants are suffering from training problem. They don't get any training from the private and government recruiting agencies before predeparture.

5. The migrant people of Bangladesh are regularly facing passport collection problem because with the introduction of machine readable passport people are compelled to travel all the way from their village and wait a week to get their passport.

6. Migrant workers of Bangladesh often face emergency problems like cheating, frauds and so on within and outside the country.

7. Migrant workers of Bangladesh are regularly encountering various problems in sending remittances, especially to the remote areas of the country, through formal channels because the process of sending remittance through banks is slow and complicated.

8. Bangladeshi migrants are regularly harassed and sometime physically oppressed in the various airports of the country.

9. Migrant workers of Bangladesh are regularly facing investment problem because of chaotic political environment.

10. The present pre-departure legislation of Bangladesh is quite vague and complicated and it creates tremendous problems for migrants.

\section{Policy Recommendations}

The remittance is the second largest income sector of Bangladesh, next to the export sector (Ministry of Expatriates' Welfare and Overseas Employment, Bangladesh and Bangladesh Bank Report, 2012). The government of Bangladesh has been paying the various government and nongovernment import bills and the installments of various foreign debts \& donations from the remittance income. The remittance income has also contributed to boost up the foreign exchange reserve, per capita income and employment opportunities. Thus, the government should take the following necessary measures to save the significant income generating sector of Bangladesh: 
I) The government should establish information booth or center in Union, Upzila and Zila Parished throughout the country so that the people can collect relevant necessary information from these booths/ centers. The government of Bangladesh should also establish these opportunities \& facilities in abroad where migrant workers are employed. If the government could establish these opportunities $\&$ facilities for the migrant workers within and outside the country then the people would be able to reduce their problems and it will create trust \& confidence on government.

II) The government should set-up the certain amount as expenditure that have to be submitted by the migrant workers to the recruiting agencies and it must be applicable for both the private \& public recruiting agencies. In addition to that the government may provide financial subsidy \& bank loan to migrant workers. However, the government should eliminate additional taxes to workers.

III) The government should establish different training \& learning centers so that the migrant workers could learn about language, behavior, culture, norms, values, behavior, working \& geographical environment and so on before going to abroad. The private recruiting agencies have also to establish different training \& learning centers in order to train -up their sending people before predeparture.

IV) The government and private recruiting agencies should send the trained people abroad so that they can fight \& survive with the migrant workers of other countries in their working place.

V) The government should take quick decision to distribute passport according to particular village or district in a particular day or time. If government could distribute passport from the respective village or district in particular day or time then the cost and time for getting passport would be more affordable. The government may use information technologies to facilitate the process.

VI) The government should arrange emergency phone numbers and services for migrant workers within and out the country and should these provide to them so that they contact and seek assistance.

VII) The government and private banks should increase the speed of their services throughout the country and also decrease the paper work \& documentation, which make it very simple \& easy for less educated or illiterate migrant workers to send their remittances through formal channel.

VIII) The government should take necessary legal actions against those people who are involved with undisciplined activities in the airports of the country.

IX) The government should create investment friendly environment in order to use the remittance money in productive sector. Otherwise, the large part of

Copyright $(C 2013$, Asian Business Consortium | ABR the remittance money will spend in consumption purpose by the family members \& relatives of the migrant workers.

X) The government should formulate clear and precise pre-departure legislation so that the migrant workers can easily understand which will encourage them to follow.

XI) Migrant workers face lots of problems in abroad due to lack of information, knowledge \& education. The government and private recruiting agencies should expand their training centers in different parts of the country in order to reduce this problem. The return workers may help prospective workers by giving basic knowledge like how to use toilets, how to talk/ behave with employers, how to proceed in the airport and others, which will minimize the conflicts between employers and migrant workers that creates a bad reputation of Bangladeshi workers.

\section{OPPORTUNITIES OF REMITTANCE INCOME IN BANGLADESH}

Bangladesh has earned a record amount of foreign remittance amounting more than $\$ 14$ billion and exported the second highest number of workers to Middle- East Countries (Ministry of Expatriates' Welfare and Overseas Employment Report, 2012). It has been indicated that the demand for blue-collar workers are increasing day-by-day in Asian countries, especially Middle -East and South-East Asian countries. The World Cup Football 2022 will be held in Qatar. That is why, the authority of this country wants to import huge number of labor from Bangladesh. Thus, the government of Bangladesh should start diplomatic and high profile discussion with the government of Qatar immediately to catch the labor market of this country so that the government can export huge number of labor to Qatar and earn ample foreign remittance. Beside this, the government should take necessary steps to open the labor market of Kuwait for fresh migrant workers of Bangladesh promptly and should also arrange bilateral and multilateral discussion with the other countries of the Middle-East which will help the government to expand the labor market in the Middle-East countries.

Recently, Malaysia has been agreed to take labor from Bangladesh. Now, the government is trying to collect required number of qualified labor through mass campaign from every district of Bangladesh. In this case the government should be very much careful so that the Malaysian labor market will not be stopped again for Bangladesh migrants. In addition to Malaysia, the government of Bangladesh should arrange bilateral and multilateral discussion with the government of other Asian and MiddleEast countries so that our migrants will get more employment facilities in these countries.

The shortage of certain skilled professionals in industrialized countries such as information technology experts and 
computer specialists, nurses, medical doctors, etc. is an important factor behind the increase in demand for skilled manpower. In recent years, the OECD countries have encouraged immigration of high skill people through immigration incentive policies such as $\mathrm{H}-1$ professional Visas in the U.S. and special visas for information technology experts in Germany and other countries. In this regard, the government of Bangladesh emphasis on developing the skill level of potential migrants through various training program so that the Bangladeshi migrants will get migration opportunities in the OECD and other countries in the world.

Still today, the African Continent is under the un-invented condition. Now, the government of developed countries has been drawn special attention to develop the various countries in this continent. Thus, the government of Bangladesh should start bilateral and multilateral discussion immediately so that Bangladesh can export huge labor to the various countries of African Continent. In addition to this, the government should start diplomatic and high profile discussion with the government of Latin American counties because there are tremendous opportunities to export Bangladeshi labor to these countries.

\section{Concluding Remarks}

One of the most significant foreign currency earning sectors of our country is manpower exporting. The flow of remittance has influenced directly and indirectly by many factors. One of the important direct factors is competition. There are many countries exporting workers abroad. Thus, Bangladeshi migrant workers must face tremendous competition with the workers of other countries in the foreign land. For instance, the government of Bangladesh should pay special attention to develop the skills of workers and also should take necessary measures to build-up the mutual trust and good relation with the various countries in the world for saving the valuable income generating sector of the country.

\section{FUtURE RESEARCh DIRECTION}

Despite some limitations, the present study provides some guidelines for future study which are as follows:

First, this study has conducted only on data and information from 2003-2012 (November). The amount of data and information in this study is inadequate in comparison with whole data and information. A similar study can be conducted to know the real scenario of remittance income of Bangladesh on the data and information from 1976 to till date. Such study on extended data and information either may accept or reject the present findings.

Second, this study is prepared by using only secondary data and information to know the remittance income of Bangladesh. Another study may be conducted by collecting sufficient primary data and information with the structured questionnaire to reveal the actual remittance income of Bangladesh and its opportunities and challenges.

Third, this study has conducted to find out the overall remittance income of Bangladesh. A further study may be conducted to find out the country wise or continent wise remittance income of Bangladesh and also to find out the individual country or continent problems and opportunities which are regularly facing by migrant workers of Bangladesh.

Finally, this study has conducted on male and female migrant workers of Bangladesh. But gender-wise remittance income has not studied. Thus, a study may be conducted on male and female migrant workers of Bangladesh separately to find out their contribution towards the remittance income of Bangladesh.

\section{REFERENCES}

Ali, S.A (1981). An Analysis of the Institute of Home Remittance by Bangladeshi Workers Abroad on the National Economy in Labor Migration from Bangladesh to Middle East, The World Bank Staff Working Paper No. 454, Washington, D.C

Bangladesh Association of International Recruiting Agents (BAIRA) Report, 2012.

Bangladesh Bank Research Report 2012.

Bangladesh Bank: www.bb.org.bd

Bangladesh Bureau of Statistics, 2012.

Bangladesh Economic Update, 2011 and 2012.

Bureau of Manpower, Employment and Training Report, 2012.

Hussain, Zahid and Naeem, Farria (2009). Remittances in Bangladesh: Determinents and 2010 Outlook, WealthDaily.com/Income_Invest

Kalerkantho Daily Newspaper, January 10, 2013, Dhaka, Special Issue: www.kalerkantho.com

Ministry of Expatriates' Welfare and Overseas Employment, Bangladesh, Statistics, 2012.

Osmani, S.R. (2004). The Impact of Globalization on Poverty in Bangladesh, ILO, Geneva and Dhaka.

Puri, S and Ritzema, T. (2001). Migrant Workers Remittances, Microfinance and the Informal Economy: Prospects and Issues, Working Paper No. 21, International Labor Office.

Salim, R. A. (1992). Overseas Remittances in Bangladesh: Importance, Potentialities and Policy Options, The Jahangirnagar Review, Part II, Social Science: Vois. XIII \& XIV, The Jahangirnagar University, Dhaka.

Star Business Report, 2012.

United Nations Development Programs, Dhaka, Bangladesh, Bangladesh Migration and Remittances 080120.doc

Wikipedia, The Free Encyclopedia, Latest Version.

World Bank Report 2012. 